\title{
PENGEMBANGAN LEMBAR KERJA PESERTA DIDIK BAHASA JEPANG BERBASIS KURIKULUM 2013 REVISI UNTUK SEKOLAH DASAR DI BALI
}

\author{
P.A. Wulandari ${ }^{1}$, D.M.S. Mardani ${ }^{2}$, I.W. Sadyana ${ }^{3}$ \\ ${ }^{123} J u r u s a n$ Bahasa Asing, Universitas Pendidikan Ganesha, Singaraja, Bali \\ e-mail : awulandari686@gmail.com, desak.mardani@undiksha.ac.id,
} wayan.sadyana@undiksha.ac.id

\begin{abstract}
Abstrak
Penelitian ini bertujuan untuk mengembangkan LKPD bahasa Jepang tahap awal yang sesuai dengan kurikulum 2013 revisi untuk sekolah dasar di Bali. Penelitian ini merupakan penelitian dan pengembangan yang menggunakan model pengembangan 4D model dari Thiagarajan yang terdiri dari define, design, develope, dan disseminate. Karena keterbatasan penelitian, tahapan disseminate tidak dilakukan. Data dikumpulkan dengan wawancara dan angket, dan dianalisis secara deskriptif kuantitatif dan deskriptif kualitatif. Hasil dari penelitian ini yaitu (1) LKPD bahasa Jepang tahap awal yang dikembangkan memuat 4C, HOTS, PPK dan Literasi. Dalam LKPD terdiri dari 15 materi. Setiap materi memuat 3 kegiatan dengan level kegiatan di buat dari yang mudah, menengah, hingga sulit. LKPD juga dilengkapi dengan gambar yang menarik. (2) Berdasarkan hasil uji validasi ahli, LKPD yang dikembangkan memperoleh nilai sebesar $97,84 \%$ dengan kategori sangat layak. (3) Berdasarkan uji coba terbatas, LKPD memperoleh nilai sebesar $90,35 \%$ dengan kategori sangat layak. Dapat disimpulkan bahwa LKPD bahasa Jepang tahap awal yang dikembangkan untuk sekolah dasar di Bali sudah sesuai dengan kurikulum 2013 revisi dan dapat digunakan untuk kegiatan pembelajaran bahasa Jepang.
\end{abstract}

Kata kunci: lembar kerja peserta didik, kurikulum 2013 revisi, penelitian dan pengembangan (R\&D)

要旨

本研究の目的はバリ島の小学校を向け、2013 年改正カリキュラムに基づく初期の日本語のワー クシートを開発するためである。 本研究は調查開発研究(research and development)であり、 Thiagarajan の 4D モデル「定義 - 設計 - 開発 - 普及」を使用して開発された。時間の制約のため、普 及の段階は実行されなかった。データはインタビュー、アンケートによって収集し、定量的および定 性的記述法により分析した。結果、（1）開発された初期の日本語のワークシートには 4C, HOTS, PPK, 識字が含まれている。ワークシートには 15 のテーマが含まれている。各テーマには 3 つの活動 があり、活動レベルは簡単、中、難しいの 3 つに分かれている。ワークシートには面白いい絵も付い ている。（2）専門家へのアンケートの結果、含量の資格が「非常に適切」、総点は 97,84 点であっ た、（3）それに、実現可能性検討へのアンケートの結果が「非常に適切」、総点は 90.35 点であっ た。バリ島の小学校向け、2013 年改正カリキュラムに基づく開発された初期の日本語のワークシー 卜は日本語学習活動に使用できると結論つけることができる。

キーワード : 教本、2 013 年カリキュラム、調査開発研究 (research \& development)

\section{Pendahuluan}

Di Indonesia saat ini, proses pembelajaran sudah dituntut untuk menggunakan kurikulum 2013 revisi yang didasarkan pada keterampilan abad-21 (yang diatur dalam Permendikbud No. 22/2016 tentang standar proses pembelajaran pada pendidikan dasar dan pendidikan menengah) yaitu Penguatan Pendidikan Karakter/PPK, Literasi, 4C (Communication, Collaboration, Critical thinking and Problem solving, dan Creativity and Innovation), serta HOTS (Higher Order Thinking Skills). Penerapan kurikulum 2013 revisi diterapkan pada semua jenjang baik jenjang sekolah menengah ataupun jenjang sekolah dasar. Penerapannya juga meliputi semua mata pelajaran yang diajarkan termasuk mata pelajaran bahasa Jepang. Namun pembelajaran bahasa Jepang pada sekolah dasar yang masih baru menyebabkan penerapan kurikulum 2013 revisi belum maksimal. Hal ini dikarenakan perangkat pembelajaran yang ada belum seluruhnya sesuai dengan standar 
proses kurikulum 2013 revisi. Beberapa perangkat pembelajaran yang belum sesuai dengan standar proses kurikulum 2013 revisi diantaranya adalah media pembelajaran dan lembar kerja peserta didik (LKPD).

Berdasarkan hasil angket yang diberikan pada 10 sekolah dasar di Bali yang sudah menerapkan pembelajaran bahasa Jepang, diketahui bahwa sekolah yang mempunyai LKPD namun masih merujuk pada kurikulum lama adalah sebesar $36 \%$ sedangkan sekolah yang belum memiliki LKPD dan memerlukan adanya LKPD yang sesuai dengan tuntutan kurikulum 2013 revisi adalah sebesar 45\%. Adapun sekolah yang menyatakan sudah mempunyai media pembelajaran adalah sebesar $82 \%$, sedangkan sekolah yang menyatakan belum memiliki atau sudah memiliki namun masih memerlukan media pembelajaran yang sesuai adalah sebesar $45 \%$. Perbandingan tersebut menunjukkan bahwa persentase kebutuhan LKPD terhadap ketersediaannya di lapangan lebih besar dibandingkan kebutuhan media pembelajaran terhadap ketersediannya di lapangan.

Selain itu, berdasarkan hasil angket juga diketahui bahwa media pembelajaran yang sudah ada dan digunakan oleh beberapa sekolah dasar tersebut berupa media kartu bergambar yang notabene penggunaannya dapat disesuaikan dengan kurikulum 2013 revisi. Namun beberapa sekolah yang menyatakan memiliki dan menggunakan LKPD bahasa Jepang, seluruhnya masih mengacu pada kurikulum lama (KTSP) yang menekankan pemahaman berbasis teori dibandingkan praktek. Hal ini tentu belum sesuai dengan tujuan kurikulum 2013 revisi yang berlaku. Oleh karena itu, perangkat pembelajaran yang akan dikembangkan dalam penelitian ini hanya terfokus pada pengembangan LKPD yang sesuai dengan kurikulum 2013 revisi untuk memenuhi kebutuhan di lapangan.

Lembar kerja peserta didik merupakan sarana penting mengingat fungsinya selain mengutamakan praktek yang menuntut peserta didik untuk aktif dalam pembelajaran, LKPD juga dapat digunakan untuk mengukur keberhasilan peserta didik dalam memahami materi yang diajarkan. LKPD juga memuat kegiatan dan latihan yang dapat mengembangkan aspek-aspek pembelajaran meliputi aspek kognitif, afektif, dan psikomotor. Oleh karena itu, keberadaan LKPD dalam pelaksanaan kurikulum 2013 revisi mempunyai peranan penting mengingat fungsi dan peranannya sebagai panduan bagi peserta didik dalam mengembangkan aspek kognitif, afektif, dan psikomotor yang merupakan bagian dalam tujuan penerapan kurikulum 2013 revisi.

Berdasarkan pemaparan di atas, maka ditelitilah satu permasalahan mengenai pengembangan LKPD (Lembar Kerja Peserta Didik) bahasa Jepang berbasis standar proses kurikulum 2013 revisi untuk sekolah dasar di Bali.

Dalam penelitian ini, tujuan yang diharapkan adalah untuk menghasilkan lembar kerja peserta didik (LKPD) bahasa Jepang (tahap awal) berbasis standar proses kurikulum 2013 revisi yang sesuai untuk sekolah dasar di Bali. Dengan dibuatnya produk ini diharapkan dapat membantu guru dalam mengarahkan tugas-tugas peserta didik dalam pelaksanaan kegiatan latihan pengulangan ataupun latihan penerapan pada pembelajaran bahasa Jepang.

\section{Metode}

Model penelitian dan pengembangan yang digunakan dalam penelitian ini adalah four$D$ model (4D) dari Thiagarajan, S., dkk (dalam Mardani, 2020). Model pengembangan four- $D$ (4D) terdiri atas 4 tahap utama yaitu tahap pendefinisian (define), tahap perancangan (design), tahap pengembangan (develop), dan tahap penyebaran (disseminate). Model pengembangan ini dipilih karena bertujuan untuk merancang dan menghasilkan produk perangkat pembelajaran berupa lembar kerja peserta didik bahasa Jepang yang berbasis standar proses kurikulum 2013 revisi.

Pada tahap pendefinisian diperoleh informasi bahwa dari 10 sekolah dasar yang menerapkan pembelajaran bahasa Jepang di Bali, sekolah yang sudah memiliki LKPD namun masih mengacu pada kurikulum KTSP adalah sebanyak $36 \%$. Sedangkan sekolah yang belum memiliki LKPD dan membutuhkan adanya LKPD yang sesuai dengan kurikulum 2013 revisi adalah sebanyak 45\%. Dari perbandingan tersebut disimpulkan bahwa sebagian besar sekolah yang belum memiliki LKPD menyatakan membutuhkan LKPD yang sesuai dengan kurikulum 2013 revisi. Selain itu, hasil wawancara yang dilakukan dengan peserta 
didik diketahui bahwa peserta didik menyukai pembelajaran bahasa Jepang. Namun karena terbatasnya perangkat pembelajaran yang mendukung, latihan pengulangan dan latihan penerapan menjadi kurang menyenangkan dan membuat mudah bosan. Sehingga pada penelitian ini tidak hanya diperlukan LKPD yang sesuai dengan kurikulum 2013 revisi namun LKPD yang sesuai dengan karakteristik peserta didik dan dapat membantu mengarahkan tugas-tugas pembelajaran pada latihan pengulangan maupun latihan penerapan yang membuat pembelajaran menyenangkan dan tidak mudah bosan. Pada tahapan pendefinisian ini, data yang diperoleh merupakan data dari hasil angket yang diisi oleh guru pengajar dan data hasil wawancara terstruktur pada peserta didik di masing-masing sekolah dasar.

Setelah mendapatkan permasalahan dari tahap pendefinisian, selanjutnya dilakukan tahap perancangan. Tahap perancangan yang dilakukan meliputi: pemilihan media (media selection), pemilihan format (format selection), dan desain awal (initial design). Pemilihan media dilakukan untuk mengidentifikasi LKPD yang relevan dengan karakteristik materi dan sesuai dengan kebutuhan peserta didik. Selanjutnya dilakukan pemilihan format. Pemilihan format dalam pengembangan ini dimaksudkan dengan mendesain isi pembelajaran, pemilihan pendekatan, dan sumber belajar, mengorganisasikan dan merancang isi LKPD, dan membuat desain LKPD yang meliputi desain layout, gambar, dan tulisan. Setelah dilakukan pemilihan media dan pemilihan format, tahap perancangan dilanjutkan pada pembuatan desain awal. Desain awal yang dihasilkan berupa rancangan kegiatan atau tugas-tugas dalam LKPD.

Setelah dihasilkan rancangan awal pada tahap perancangan, kemudian dilanjutkan dengan merealisasikan rancangan awal LKPD. Dalam tahap pengembangan ini, dilakukan pembuatan desain kegiatan, desain ilustrasi pendukung dalam kegiatan, desain sampul dan pencetakan LKPD. Selain itu juga dalam tahap ini dilakukan penentuan rancangan pengembangan model kegiatan yang sesuai dengan karakteristik peserta didik. Setelah rancangan produk LKPD terealisasikan, selanjutnya dilakukan tahap validasi ahli (expert appraisal). Tahap uji validasi ahli dilakukan dengan memberikan instrumen penilaian berupa angket yang memuat penilaian didasarkan pada 3 syarat utama pengembangan LKPD yaitu syarat didaktif, syarat konstruktif, dan syarat teknis (Prastowo, 2013).

Setelah tahap uji validasi ahli dilakukan, selanjutnya LKPD dilakukan perbaikan yang kemudian dilanjutkan pada tahap uji coba. Dalam penelitian ini, uji coba produk dilakukan terbatas. Tahapan dalam uji coba produk meliputi uji ahli praktisi dan uji coba pengguna terbatas. Uji ahli praktisi dilakukan oleh guru pengajar dari SD Mutiara Singaraja. Setelah dilakukan uji ahli praktisi oleh guru pengajar, selanjutya dilakukan uji coba pengguna terbatas. Uji coba pengguna terbatas dilakukan kepada 26 orang peserta didik dari SD Mutiara Singaraja. Dalam hal ini, instrumen yang digunakan berupa angket uji ahli produk dan angket penilaian tanggapan.

Adapun teknik analisis data dilakukan dengan cara analisis interpretatif dibantu dengan teknik triangulasi. Dimana data yang didapat dari instrumen yang diisi oleh responden ditabulasi. Selanjutnya data informasi yang telah diperoleh dari instrumen angket dianalisis dengan pendekatan deskriptif kualitatif.

Adapun hasil angket uji validasi dan uji ahli praktisi dianalisis dengan teknik analisis sebagai berikut. Bobot penilaian dari hasil data angket dijumlahkan masing-masing responden. Setelah mendapatkan skor atau jumlah jawaban total dari masing-masing responden, skor kemudian dipersentasekan menggunakan rumus persentase persetujuan (Sugiyono, 2012) sebagai berikut.

Keterangan:

$$
P=\frac{f}{n} \times 100 \%
$$

$P=$ Persentase jawaban

$f=$ Frekuensi jawaban dari responden

$n=$ Skor maksimum 


\section{$100 \%$ merupakan bilangan tetap}

Setelah diperoleh hasil persentase, kemudian untuk menghitung skor rerata dari seluruh responden digunakan rumus sebagai berikut.

Keterangan:

$$
\bar{x}=\frac{\Sigma P}{N}
$$

\section{$\bar{x}=$ Skor rata-rata}

$N=$ Jumlah responden

$\Sigma P=$ Jumlah persentase total dari seluruh responden

Adapun hasil rata-rata dari persentase yang telah dihitung, kemudian ditentukan skala jawabannya melalui pengkategorian kelayakan skala likert (menurut Arikunto dalam lis dan Totok : 2017) berdasarkan kriteria sebagai berikut.

Tabel 1. Skala Kriteria Kelayakan

No. Skor dalam persen Kategori Kelayakan

\begin{tabular}{ccc}
\hline 1. & $<21 \%$ & Sangat Tidak Layak \\
\hline 2. & $21-40 \%$ & Tidak Layak \\
\hline 3. & $41-60 \%$ & Cukup Layak \\
\hline 4. & $61-80 \%$ & Layak \\
\hline 5. & $81-100 \%$ & Sangat Layak \\
\hline
\end{tabular}

Selanjutnya untuk hasil angket uji coba terbatas terhadap peserta didik diinterpretasikan dengan menggunakan rumus hitung sebagai berikut. Setelah didapatkan hasil jawaban dari masing-masing responden, untuk melihat bobot masing-masing tanggapan dan menghitung skor rerata yang kemudian dipresentasekan menggunakan rumus persentase persetujuan (Sugiyono, 2012) sebagai berikut.

Keterangan:

$$
P=\frac{f}{n} x 100 \%
$$

$P=$ Persentase jawaban

$f=$ Frekuensi jawaban dari responden

$n=$ Skor maksimum

$100 \%$ merupakan bilangan tetap

Adapun hasil rata-rata dari persentase yang telah dihitung, kemudian ditentukan skala jawabannya melalui pengkategorian kelayakan skala likert (menurut Arikunto dalam lis dan Totok : 2017) berdasarkan kriteria sebagai berikut.

Tabel 2. Skala Kriteria Kelayakan

\begin{tabular}{ccc}
\hline No. & Skor dalam persen & Kategori Kelayakan \\
\hline 1. & $<21 \%$ & Sangat Tidak Layak \\
\hline 2. & $21-40 \%$ & Tidak Layak \\
\hline 3. & $41-60 \%$ & Cukup Layak \\
\hline 4. & $61-80 \%$ & Layak \\
\hline 5. & $81-100 \%$ & Sangat Layak \\
\hline
\end{tabular}

Setelah LKPD direvisi berdasarkan masukan pada tahap uji ahli dan uji coba, kemudian dilakukan pencetakan LKPD. Selanjutnya, tahap penyebaran produk (disseminate) tidak dilakukan mengingat keterbatasan waktu penelitian. 


\section{Hasil dan Pembahasan}

Hasil utama dari penelitian ini adalah LKPD atau lembar kerja peserta didik bahasa Jepang untuk sekolah dasar yang berbasis standar proses Kurikulum 2013 revisi yang dicirikan dengan adanya 4C (Communication, Collaboration, Critical thinking and Problem solving dan Creativity and Innovation) dan HOTS (Higher Order Thinking Skills) didalamnya. LKPD ini terdiri dari 15 materi yang termuat ke dalam 15 bab yang terdiri atas (1) Aisatsu, (2) Jikoshoukai, (3) Bangou (1-20), (4) Iro, (5) Youbi, (6) Karada, (7) Watashi no Kazoku, (8) Diah-san no Kazoku, (9) Bangou (21-100), (10) Nenrei, (11 )Tanjoubi, (12) Jikan, (13) Norimono, (14) Gakkou de, (15) Kyoushitsu no naka de.

Dalam setiap bab terdiri dari judul materi dalam bab, kompetensi dasar (KD), dan indikator yang sudah disesuaikan dengan silabus rujukan serta kegiatan dalam LKPD. Terdapat 3 kegiatan dalam setiap bab yang tingkat kesulitan kegiatannya dibuat dari yang mudah, menengah, hingga sulit. Setiap kegiatan memuat langkah-langkah kegiatan, media berupa alat atau bahan yang harus dipersiapkan, pertanyaan serta kegiatan yang harus dilakukan hingga dapat menarik suatu kesimpulan. LKPD tersebut juga disajikan dengan menggunakan huruf romaji yang dilengkapi dengan ilustrasi gambar.

Pada sampul depan LKPD, dicantumkan judul "LKPD" dengan sub judul "Lembar Kerja Peserta Didik Bahasa Jepang 1" untuk siswa sekolah dasar. Selain itu, pada sampul depan LKPD juga terdapat kalimat "Disesuaikan dengan Kurikulum 2013 Revisi Terbaru".

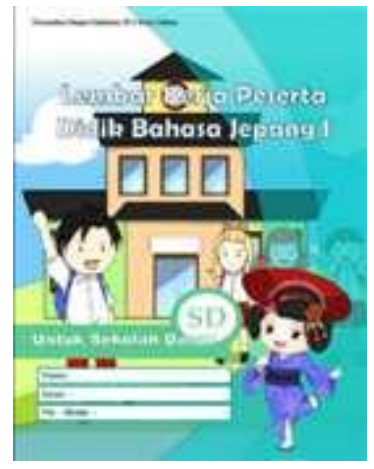

\section{Gambar 1. Sampul Depan LKPD}

Pada sampul belakang LKPD, pemilihan warna background disesuaikan dengan pemilihan warna pada sampul depan agar dihasilkan perpaduan warna yang selaras. Pada sampul belakang LKPD dijelaskan mengenai keunggulan LKPD yang dijabarkan secara rinci.

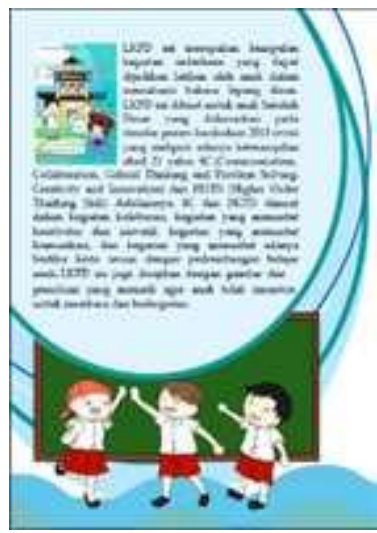

\section{Gambar 2. Sampul Belakang LKPD}

LKPD bahasa Jepang yang berbasis standar proses kurikulum 2013 revisi telah memperoleh status valid pada tahapan uji validasi ahli dengan perolehan nilai persentase sebesar 97,8\% dengan kategori "Sangat Layak". Selain itu, LKPD ini juga memperoleh 
status praktis terkait kesiapan penerapannya di lapangan. Status praktis memperoleh nilai persentase sebesar $88,9 \%$ dengan kategori "Sangat Layak". Adapun untuk respon pengguna produk diperoleh nilai persentase sebesar 91,79\% dengan kategori "Sangat Layak". Sehingga berdasarkan seluruh nilai persentase dan kriteria kelayakan tersebut, maka disimpulkan bahwa LKPD bahasa Jepang berbasis standar proses kurikulum 2013 revisi dinyatakan dalam kualifikasi sesuai dengan kondisi yang dibutuhkan dan sangat layak untuk digunakan.

Setelah dilakukan uji validasi ahli dan uji coba terbatas, selanjutnya dilakukan revisi produk guna memperoleh LKPD draft III atau draft final. Adapun revisi produk LKPD yang dilakukan adalah sebagai berikut.

\section{Perbaikan desain gambar dan warna LKPD}

Pada awalnya, desain warna dan gambar pada LKPD menggunakan gambar yang diadopsi dari berbagai sumber di internet. Setelah mendapatkan masukan dari validator ahli, selanjutnya dilakukan revisi pada keseluruhan gambar LKPD. Gambar dikembangkan sendiri oleh penulis menyesuaikan dengan tema dari setiap materi dalam LKPD. Gambar yang termasuk ke dalam perbaikan merupakan gambar ikon dari produk LKPD yang akan dikembangkan, gambar beberapa judul bab dalam LKPD, dan gambar beberapa kegiatan dalam LKPD.

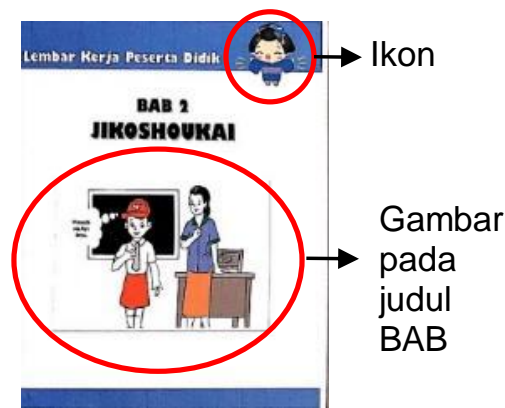

Gambar 3 Ikon dan Gambar Salah Satu Judul Bab Sebelum Direvisi

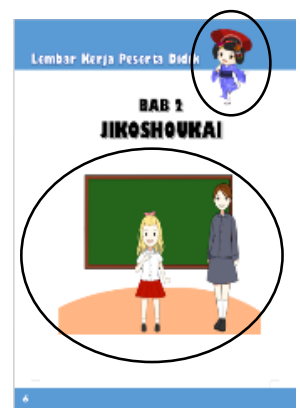

Gambar 4 Ikon dan Gambar Salah Satu Judul Bab Setelah Direvisi

Perbaikan dalam kesalahan penulisan, penambahan kata dalam kalimat dan pengurangan kata dalam kalimat

Berdasarkan validasi oleh ahli, di dalam LKPD terdapat beberapa kesalahan penulisan, terdapat kata yang tidak efektif dalam kalimat sehingga tidak perlu digunakan, dan adanya kalimat yang kurang sehingga perlu adanya penambahan kata yang sesuai. Pada desain gambar bab 1 dalam LKPD yang berjudul Aisatsu terdapat kalimat "Ohayou gozaimasu, sensei”. Berdasarkan masukan ahli, kata sensei tidak perlu dituliskan.

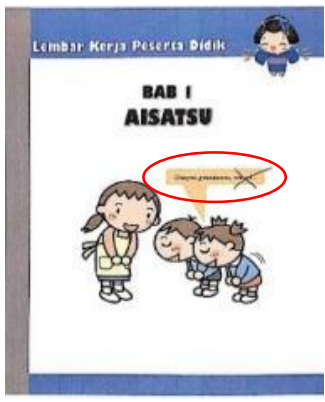

Gambar 5. Format

Penulisan Pengurangan Kata Sebelum Direvisi

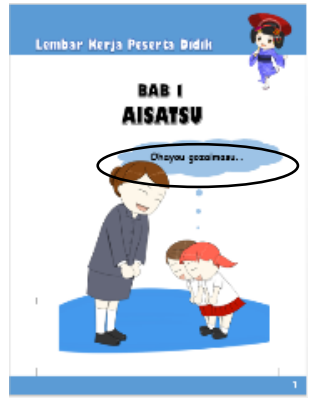

Gambar 6. Format Penulisan Pengurangan Kata Setelah Direvisi 
Pada bab 1 kegiatan 2 dalam LKPD, terdapat kalimat "Midori san, kore". Berdasarkan masukan ahli kalimat tersebut perlu ditambahkan kata "douzo" di akhir kalimat. Kata "douzo" ditambahkan sebagai penekanan.

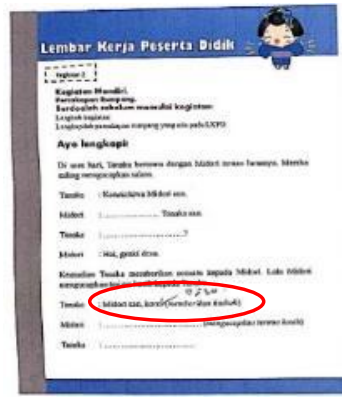

Gambar 7. Format Penulisan Penambahan Kata Sebelum Direvisi

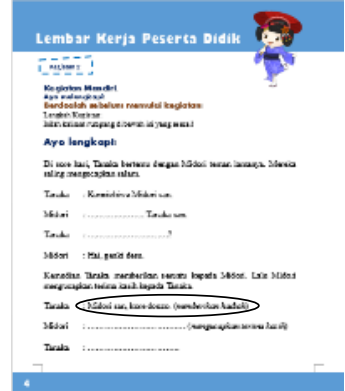

Gambar 8. Format Penulisan Penambahan Kata Setelah Direvisi

Pada bab 2 kegiatan 1 terdapat kata "karakimashita". Berdasarkan masukan dari ahli penulisan "karakimashita" seharusnya dipisah menjadi dua kata "kara" dan "kimashita". Selain itu, penulisan "kiiro" yang seharusnya ditulis "kiiroi" dan penulisan "pinkgu" yang seharusnya ditulis "pinku".

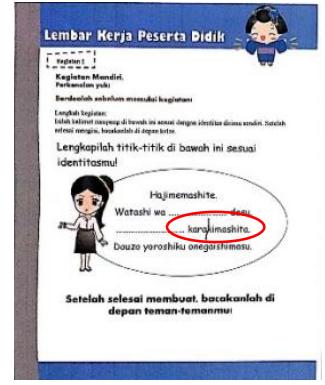

Gambar 9. Kesalahan Penulisan kara kimashita Sebelum Direvisi

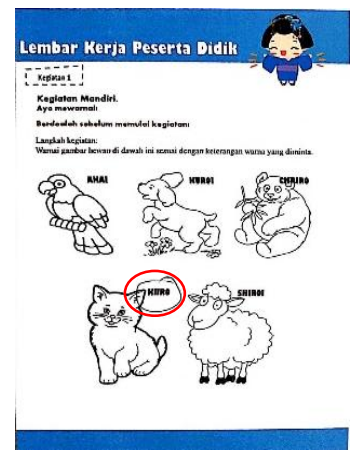

Gambar 11. Kesalahan Penulisan kiiroi Sebelum Direvisi

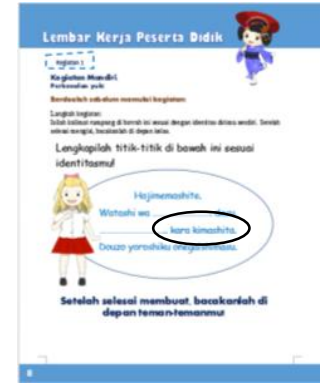

Gambar 10. Kesalahan Penulisan kara kimashita Setelah Direvisi

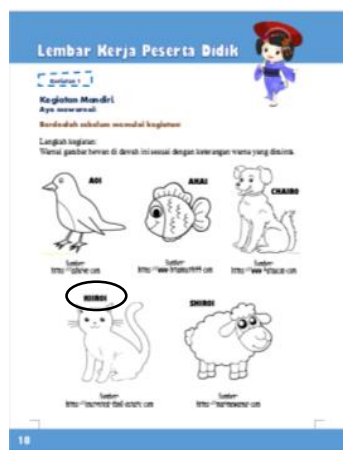

Gambar 12. Kesalahan Penulisan kiiroi Setelah Direvisi 

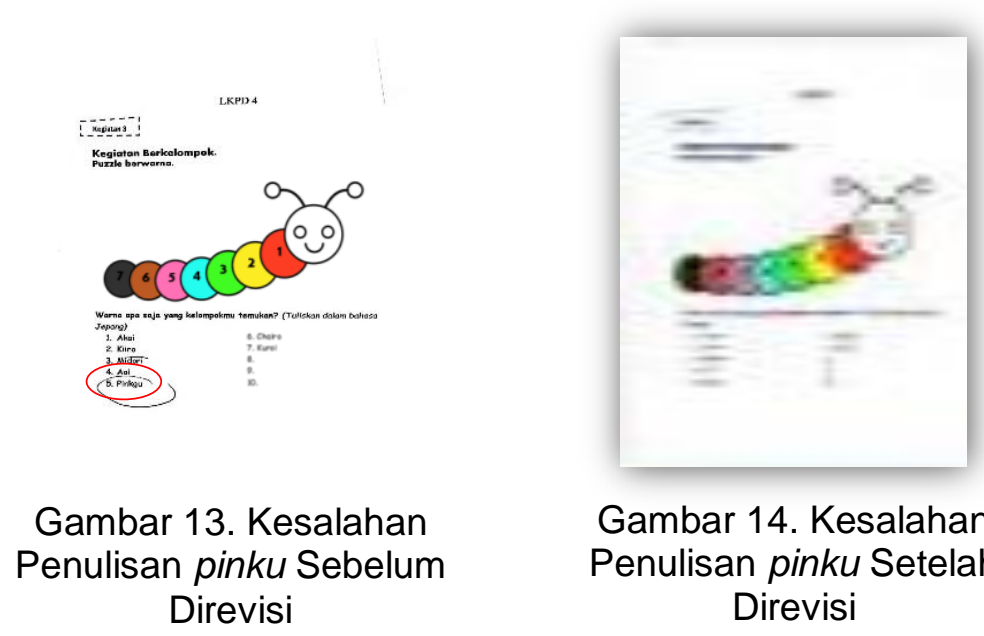

Gambar 14. Kesalahan

Penulisan pinku Setelah

Direvisi

Direvisi

Perbaikan desain kegiatan dalam LKPD

Pada desain kegiatan bab 2 kegiatan 2 terdapat 12 kotak warna yang berbeda dan bertuliskan nama bulan. Dalam 12 kotak tersebut terdapat warna yang hampir sama dan letaknya berdekatan. Menurut masukan ahli penggunaan warna pada kotak tersebut sebaiknya tidak hampir sama dan diletakkan tidak berdekatan.

Selain itu, pada kunci jawaban LKPD 6 kegiatan 1 terdapat jawaban ambigu terkait nama anggota tubuh yang ditunjuk dalam soal. Berdasarkan masukan ahli, perlu diperbaiki kualitas gambar dan penanda soal dibuat lebih jelas.

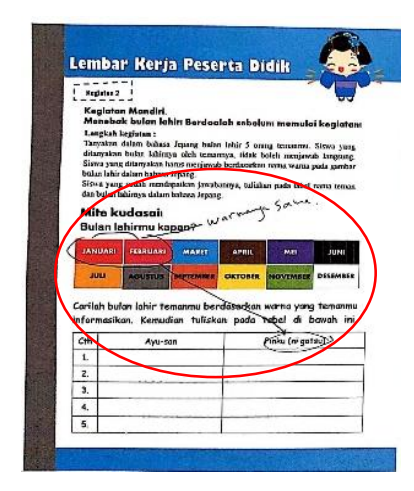

Gambar 15. Desain Bab 2 Kegiatan 2 Sebelum Direvisi

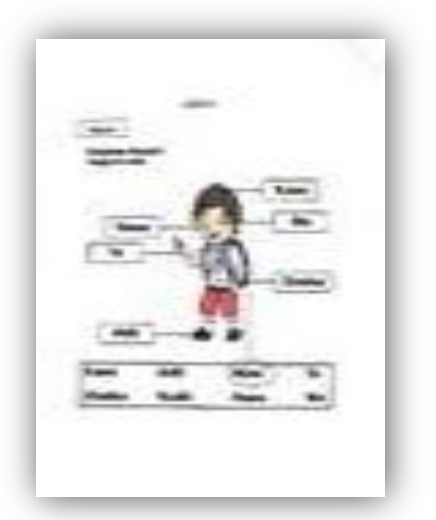

Gambar 17. Desain Kegiatan 1 LKPD 6 Sebelum Direvisi

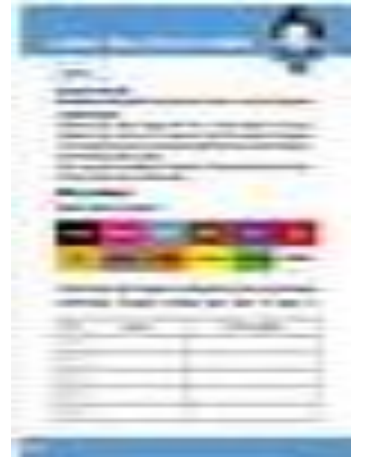

Gambar 16. Desain Bab 2 Kegiatan 2 Setelah Direvisi

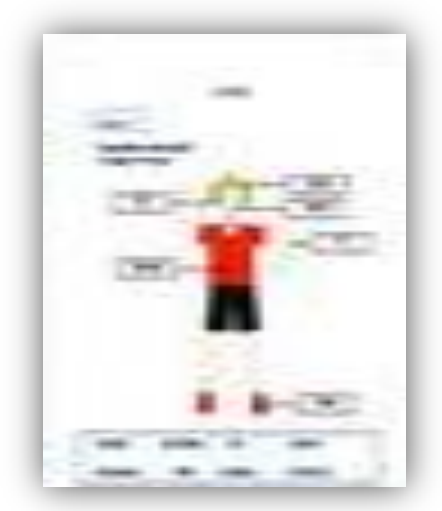

Gambar 18. Desain Kegiatan 1 LKPD 6 Setelah direvisi 
Berdasarkan latar belakang yang telah dipaparkan, penelitian dan pengembangan ini dilakukan karena belum tersedianya perangkat pembelajaran berupa lembar kerja peserta didik (LKPD) bahasa Jepang berbasis kurikulum 2013 revisi yang sesuai untuk pembelajaran bahasa Jepang pada sekolah dasar di Bali.

Selanjutnya dalam pengembangan LKPD ini, digunakan desain pengembangan four-D model. LKPD yang dikembangkan dalam penelitian ini terdiri dari 15 materi yang termuat dalam 15 bab yang telah disesuaikan dengan silabus rujukan berstandar kurikulum 2013 revisi dan buku ajar rujukan berjudul "Uki-Uki Manabo" yang juga sudah disesuaikan dengan kebutuhan peserta didik. LKPD yang dikembangkan juga telah disesuaikan dengan silabus rujukan yang berbasis pada standar proses kurikulum 2013 revisi dengan mengintegrasikan PPK (Penguatan Pendidikan Karakter), Literasi, 4C (Communication, Collaboration, Critical Thinking and Problem Solving, dan Creativity and Inovation) dan HOTS (Higher Order Thinking Skill) didalamnya. Di dalam PPK terdapat 5 hal yang ditekankan meliputi religius, nasionalis, gotong royong, mandiri dan integritas. 5 hal tersebut dimuat secara tidak langsung dalam LKPD. Literasi dalam LKPD juga dimuat secara tidak langsung yakni pada kegiatan membaca maupun menulis dalam LKPD dan membaca sumber lain terkait pengetahuan yang diperlukan baik berupa sumber cetak, visual ataupun digital untuk mendukung pengerjaan tugas-tugas dan kegiatan dalam LKPD. Sedangkan 4C dapat dilihat dari adanya kegiatan kolaborasi oleh peserta didik, kegiatan yang menuntut kreativitas dan inovatif, kegiatan yang menuntut peserta didik dapat mengamati, menganalisis, menyimpulkan serta mengkomunikasikan hasil kegiatannya, dan kegiatan yang menuntut peserta didik dapat berfikir kritis sesuai dengan perkembangan belajarnya.

Kegiatan berpikir kritis ini disajikan dalam LKPD berupa pertanyaan-pertanyaan yang tidak langsung memberikan jawaban melainkan pertanyaan pertanyaan yang menuntut adanya pemecahan masalah untuk dapat menjawabnya. Kegiatan berpikir kritis ini dirancang sederhana dengan tetap memperhatikan perkembangan kognitif pada anak SD yang menurut Piaget tingkat perkembangannya berada pada tahap operasional konkret yang ditandai dengan kemampuan berpikir konkret dan mendalam, serta mampu mengontrol persepsinya. Dalam kegiatan berpikir kritis, HOTS (Higher Order Thinking Skills) juga terintegrasi didalamnya. HOTS merupakan keterampilan berpikir tingkat lanjut daripada LOTS (Low Order Thinking Skill) yang meliputi 3 level lanjutan pada tingkatan kognitif Taksonomi Bloom yang meliputi level menganalisis, mengevaluasi, dan mencipta. Namun dalam LKPD ini, HOTS yang diintegrasikan hanya pada sampai level menganalisis mengingat tingkat perkembangan kognitif pada anak SD masih pada tahap operasional konkret. Pada LKPD bahasa Jepang tahap 1 ini, kompetensi yang akan dikembangkan mencakup ranah kognitif Taksonomi Bloom yang meliputi LOTS dan HOTS yaitu C1 (ingatan), C2 (pemahaman), C3 (penerapan), dan sedikitnya C4 (analisis).

Sebelum produk LKPD dinyatakan layak untuk digunakan, produk LKPD ini telah melalui tahapan uji validasi oleh ahli, uji praktisi dan uji coba pengguna. Uji validasi oleh ahli dilakukan untuk memperoleh produk LKPD yang sudah berstatus valid dan layak untuk di uji cobakan. Uji validasi ahli dilakukan oleh dua validator ahli yang merupakan dosen di lingkungan Universitas Pendidikan Ganesha yang berkompeten di bidang pendidikan dan kurikulum juga di bidang pengajaran bahasa Jepang. Sedangkan uji ahli praktisi dilakukan oleh satu orang guru pengajar di SD Mutiara Singaraja. Uji ahli praktisi dilakukan guna mendapatkan status praktis terkait layak atau tidaknya LKPD diterapkan di lapangan. Selanjutnya uji coba pengguna dilakukan di SD Mutiara Singaraja dengan subjek uji coba adalah 26 orang peserta didik pembelajar bahasa Jepang dari kelas VI di SD tersebut. Uji coba pengguna dilakukan untuk mengetahui respon dari pengguna terkait produk LKPD. Hasil dari keseluruhan akan digunakan untuk menyempurnakan LKPD sehingga diperoleh LKPD final yang berstatus tepat, sesuai dan layak digunakan di lapangan.

Hasil dari uji validasi ahli terkait produk LKPD yang dikembangkan memperoleh nilai sebesar $97,84 \%$ dengan kategori Sangat Layak. Sedangkan untuk hasil uji coba terbatas terkait produk LKPD diperoleh nilai sebesar 90,35\% dengan kategori Sangat Layak. 
Tabel 3. Hasil Penilaian Uji Validasi Ahli

\begin{tabular}{ccc}
\hline Analisis Data & Skor (dalam \%) & Kategori \\
\hline Uji Validasi Ahli & 97,84 & Sangat Layak \\
\hline
\end{tabular}

Adapun hasil penilaian ujicoba terbatas disajikan dalam tabel berikut.

Tabel 4. Hasil Penilaian Ujicoba Terbatas

\begin{tabular}{ccc}
\hline Analisis Data & Skor (dalam \%) & Kategori \\
\hline Uji Ahli Praktisi & 88,91 & Sangat Layak \\
\hline Tanggapan Pengguna & 91,79 & Sangat Layak \\
\hline Total & 90,35 & Sangat Layak \\
\hline
\end{tabular}

Keberadaan LKPD juga diberikan respon yang positif dari pengajar maupun peserta didik sebagai pengguna. Pengajar menyatakan pentingnya keberadaan LKPD untuk membantu mengarahkan tugas-tugas belajar oleh peserta didik. Oleh karena itu pengajar berharap LKPD yang dihasilkan dalam penelitian ini bisa sampai pada tahap penyebaran agar dapat digunakan oleh pengajar sebagai salah satu perangkat pembelajaran yang mendukung keterampilan proses di kelas. Selain itu, peserta didik juga sangat antusias belajar dengan menggunakan LKPD yang merupakan perangkat pembelajaran yang baru bagi peserta didik dalam belajar bahasa Jepang. Peserta didik juga menyatakan bahwa LKPD bahasa Jepang 1 sangat menarik sehingga memotivasi untuk belajar.

Adapun implikasi dalam penelitian dan pengembangan ini adalah sebagai acuan guru dalam memilih kegiatan atau tugas-tugas yang harus diselesaikan peserta didik dalam belajar bahasa Jepang dasar. Kemudian dapat membantu peserta didik agar lebih termotivasi dalam mempelajari bahasa Jepang agar tidak monoton dan mudah bosan. Selain itu, LKPD ini juga dibuat berdasarkan standar proses kurikulum 2013 revisi yang sudah mengintegrasikan keterampilan abad 21 di dalamnya agar dapat mengasah peserta didik dalam berfikir kritis, kreatif dan inovatif serta dapat digunakan peserta didik sebagai referensi latihan pengulangan atau latihan penerapan bahasa Jepang.

\section{Simpulan dan Saran}

Produk LKPD ini merupakan kumpulan kegiatan sederhana yang dapat dijadikan latihan oleh peserta didik dalam memahami bahasa Jepang dasar. LKPD ini dibuat untuk anak sekolah dasar yang didasarkan pada standar proses kurikulum 2013 revisi yang meliputi adanya keterampilan abad 21 yakni 4C (Communication, Collaboration, Critical Thinking And Problem Solving, dan Creativity And Innovation) dan HOTS (Higher Order Thinking Skill) di dalamnya. 4C dan HOTS dimuat dalam kolaborasi kegiatan yang menuntut kreativitas dan inovatif, kegiatan yang menuntut komunikasi dan kegiatan yang menuntut adanya berpikir kritis. LKPD tersebut terdiri 15 pokok materi yang termuat ke dalam 15 bab yang setiap bab nya terdiri dari 3 kegiatan dimana pada setiap level kegiatan dibuat dari yang mudah, menengah, dan sulit.

Sesuai dengan perkembangan belajar anak LKPD ini juga dilengkapi dengan gambar dan penulisan yang menarik agar anak tidak mudah bosan dalam belajar bahasa Jepang melalui membaca dan berkegiatan yang menyenangkan.

Kepada guru, disarankan untuk menggunakan dan memanfaatkan LKPD ini sebagai acuan guru dalam mengarahkan tugas-tugas peserta didik melalui pemilihan kegiatan dan tugas-tugas yang sesuai dalam belajar bahasa Jepang dasar. Selain itu, LKPD ini juga sudah disesuaikan dengan standar proses kurikulum 2013 revisi, sehingga pada 
pelaksanaannya diharapkan sesuai dengan tujuan dari kurikulum yang berlaku saat ini yaitu kurikulum 2013 revisi.

Dari hasil penelitian ini, selanjutnya diharapkan agar dapat menjadi acuan bagi peneliti lain dalam melakukan penelitian yang relevan atau mengembangkan LKPD bahasa Jepang lanjutan untuk sekolah dasar yang memuat materi yang lebih luas dan kegiatan yang lebih menarik untuk mengenal bahasa Jepang. Terlebih lagi subyek penelitian dibuat lebih luas tidak hanya untuk sekolah dasar di Bali tetapi juga di luar Bali.

\section{Daftar Pustaka}

Ernawati, Ils dan Sukardiyono, Totok. 2017. Uji Kelayakan Media Pembelajaran Interaktif pada Mata Pelajaran Administrasi Server. Universitas Negeri Yogyakarta. Jurnal Elinvo (Electronics, Informatics, and Vocational Education). Volume 2, nomor 2. Tersedia pada https://journal.uny.ac.id/ (Diakses pada tanggal 10 September 2019).

Mahmudah, Siti. 2017. Pengembangan Lembar Kerja Peserta Didik (LKPD) Tematik Berbasis Scientific Pada Kelas IV, Tema 9 (Kayanya Negeriku) Subtema 2 Pembelajaran 1. Skripsi. Purwokerto: Universitas Muhammadiyah Purwokerto. Tersedia pada http://repository.ump.ac.id (Diakses tanggal 15 Juni 2019).

Mardani, DMS, dkk. 2018. Profil Pembelajaran Bahasa Jepang pada Jenjang Sekolah Dasar di Bali. Laporan penelitian (tidak diterbitkan). Jurusan Pendidikan Bahasa Jepang. Universitas Pendidikan Ganesha.

Mardani, D.M.S., Sadyana, I.W., \& Adnyani, L.D.S. 2020. Learning Japanese Language Based on 2013 Curriculum at Elementary Schools in Bali. Proceedings of the 3rd International Conference on Innovative Research Across Disciplines (ICIRAD 2019), 246-251. https://dx.doi.org/10.2991/assehr.k.200115.040 (Diakses tanggal 10 Juni 2020)

Prastowo, Andi. 2013. Panduan Kreatif Membuat Bahan Ajar Inovatif. Yogyakarta: DIVA Grafindo Persada.

Sugiyono. 2012. Metode Penelitian Kuantitatif, Kualitatif dan R\&D. Bandung: Alfabeta. 